\title{
A Systems Approach to Understanding Geopolitical Tensions in the Middle East in the Face of a Global Water Shortage
}

\author{
Raya A. Al-Masri, University of Surrey, UK \\ Theodoros Spyridopoulos, Toshiba Research Europe Ltd., UK \\ Stylianos Karatzas, University of Patras, Greece \\ Vasiliki Lazari, University of Patras, Greece \\ Theo Tryfonas, University of Bristol, UK \\ (iD https://orcid.org/0000-0003-4024-8003
}

\begin{abstract}
In this paper, the potential for conflict in the Middle East due to the depleting of regional water reserves is explored, and the implications for regional policy making, in the light of other tensions, are investigated. The authors use system dynamics to develop a model for water resources management and explore via simulation issues that emerge as important in order to highlight required policies. This analysis validates part of the existing thinking and policies in place and signifies further the need for transboundary cooperation and emphasis on areas that may not be viewed traditionally as key priorities (e.g., demand management, as opposed to continuity of supply).
\end{abstract}

\section{KEYWORDS}

Geopolitical Conflict, Middle East, System Dynamics, Water Resources Management

\section{INTRODUCTION}

There is increasing realization amongst the international community that water scarcity can have impact over countries' security and overall stability. Several factors affect the amount of water available on the planet such as variation of natural phenomena, population boom, as well as political instability in several countries. The process of climate change is also a major driver for physical and political developments related to natural resources, including water (Naugle et al., 2019). According to the FAO (2012) estimates, the rate of water use is doubling the rate of population growth worldwide, while the number of areas approaching 'risk limit' of water scarcity are increasing. Recent studies conducted by the UN research group on demand projections indicated that demand on water is anticipated to raise noticeably by almost $40 \%$ above the amount of water available in the coming two decades (Rapacioli and Malone, 2012). When assessed in conjunction with the rising drought conditions, the variability in rainfall caused by climate change (Abdulla et al. 2018, Givatia et al. 2019), as well as other uncontrollable factors such as intractable conflicts and refugees flows (Hussein et al. 2020), demand is further expected to rise. This would impose higher stress on water resources; thus, triggering tension among countries that share water bodies. In this context, several studies in the literature acknowledge that hydro-political conflict existed throughout history. Wolf et al. (2003b) found that 
little incidents were turned into a serious 'water war' condition. A number of real-life case studies, instead, presented good examples on how tension and dispute turned into productive tool to achieve sustainability in water supply. Wolf et al. (2003b); yet, argued that tension can still be identified.

Water and water-related challenges draw significant attention amongst politicians worldwide as a main subject on top of their agendas. The former UN Secretary General Kofi Anan, for instance, stressed in many locations that the potential of conflict over fresh water and 'water-wars' are anticipated as they are driven by fierce competition over water resources (Carius et al., 2004). The late King Hussein of Jordan also warned that water is predicted to initiate a war between neighbor courtiers in the long term (Wolf et al., 2009). This debate raised during the severe drought recorded in the region in the late nineties, when Israel claimed that rainfall was not sufficient to provide Jordan with the amount of water as stated in the water agreement between Jordan and Israel, as a component of the Peace Treaty signed in 1994 (Brown and Crawford, 2009; Wolf et al., 2009). Individuals, on the other hand, augment the stress over water. People believe that water is a 'human right' and a commodity to be provided for granted. This argument encourages people to negatively react in cases of water shortage or a decrease in the supply and justify their actions by claiming that securing water is a right. Intrastate tension accordingly takes place, which eventually increases dispute between riparian countries and expands interstate conflict.

Responding to the growing potential of water dispute, conflict management is becoming a vial component that governments need to incorporate in the water management strategies for countries. Admittedly, the Middle East is a vulnerable region to limited water resources, rainfall, and hydrogeopolitical tension, to name a few risks. Vulnerability also exists to internal political insecurity as well as external threats from neighbors (Van Der Molen and Hildering, 2005). Most countries in the Middle East region and North Africa endure severe water scarce conditions. Jordan is a resourcedeprived country with limited water, rainfall, and energy resources. Due to its location in a semi-arid region, rainfall in Jordan is very limited and ranges from $30 \mathrm{~mm}$ to $600 \mathrm{~mm}$ annually. Less than $1.0 \%$ of the country receives an annual rainfall of more than $500 \mathrm{~mm}$, while the majority of the areas have a rainfall rate of less than $200 \mathrm{~mm}$ per annum (UNESCO 2012). Prolonged drought periods that have been hitting the country and the impacts of climate change exacerbate water burden in Jordan. Other factors that influence water scarcity conditions are mainly related to the mismanagement of water sector in the country. Those include the disconnect between environmental and economic policies, besides the lack of effective cooperation between several institutions, which indicate that plans are proposed but not implemented. Those challenges compound the pressure on water resources in the absence of proactive plans and approaches, as well as generate negative consequences in the form of transnational dispute between neighboring countries over water. Similar analyses with respect to the security of water as a scarce resource and examined with SD are relatively less well established in the literature than food (e.g. Guma et al., 2018), electricity (e.g. Gholizad et al., 2017), or other key resources and/or utilities (e.g. e-waste, Nikabadi \& Hajihoseinali, 2018).

\section{Problem Formulation}

Key objective of this paper is to examine the extent by which water vulnerability in the Jordan River Basin (JRB) could form a reason for hydro-geopolitical conflict between riparian countries; in this case Jordan and Israel, and how such dispute, if exists, could be managed. To answer this question, a systems approach for conflict management was applied. In the water sector a number of other approaches have been developed that align with generic principles of the systems approach. For example, Biswas ed. (1976) argued that any water systems approach is undertaken by developing a water system model. Water system models are built by identifying water volume (availability) and probability. Each of the two components further entails modeling structure and modeling objectives. Examples on modeling structure cover water resources, government, public, and utilities and their relationships, whereas the modeling of objectives entails e.g. avoiding conflict by proposing best water use strategy. 
Simonovic (2009) claimed that applying the systems approach in conflict resolution plans produces advantageous outcomes. Among those outcomes are improved decision-making and management policies, as well as identifying best options available for projects improvements. This work, which is based on principles of 'Object-oriented modeling', is a simple comprehensive approach used to identifying water resource system modeling problems (Nandalal and Simonovic, 2003). Albeit the application of this concept is relatively new in the water resource sector, considerable number of cases presented in the literature stressed its significance. Examples cover cases on "river basin management and planning", "long-term water resource planning and policy" for water analysis, and "reservoir operation" (Nandalal and Simonovic, 2003). As opposed to the functional mathematical models developed by more analytical system approaches, the object-oriented model helps to effectively review and present any case resembling a 'real-world situation' in order to propose viable alternatives to face its challenges. Moreover, the method follows a comprehensive approach in solving any situation by dealing with several stakeholders and parties involved such as social, economic, and political sectors thus, increasing the quality of the outcome of the analysis (Nandalal and Simonovic, 2003). To better achieve the goals of any conflict resolution process in terms of eliminating tension between parties, the process shall meet the requirements of all stakeholders involved (Nandalal and Simonovic, 2003). Within this context, Nandalal and Simonovic (2003) identified a number of activities needed before commencing, and during the application of, any conflict resolution plan. The key activities include "communication support", problem identification, data collection, information production, information sharing, and assessment of the outcomes of the actions taken. During the process of developing a resolution policy, those activities are required to be followed in sequence so that a mutual agreement between all parties engaged in the process is approved and accepted.

In this paper we aim at employing systems dynamics as a fundamental approach to investigate the casual relationship between three main indicators: water scarcity in Jordan and in the JRB in particular, a number of factors that affect water quantities in the river basin, and the potential for geopolitical conflict over the JRB between Israel and Jordan accordingly. The findings would help Jordan to identify shortcomings in water sector policies related to dispute assessment and resolution; thus, adopt systematic and organized plans that are proactive and preventive to reduce or eliminate the geopolitical impacts of transboundary resources.

The water situation in Jordan is further worsened given that the JRB - the main surface water resource in the country - is shared by four riparian countries on the borders. Syria and Lebanon are bordering the basin from the north, whereas Israel and Palestine are bordering the lower southern part of the basin. In addition to the increasing demand, expanding population, urbanization, and natural water-deficit catalysts such as limited rainfall and high temperatures, certain national practices on the river basin may escalate tension between the riparian counties. Ragab and Prudhomme (2002) argue that physical water sacristy and retaining freshwater resources near the Israeli side, besides the drainage of Jordan River aquifers by Israeli boreholes toward Israeli territories has been augmenting tension between Israel and its neighbors over water (Van Der Molen and Hildering, 2005). In this respect, the JRB has been gaining a particular attention in the literature from local as well as international researchers in order to assess the hydro politics of the river basin, and identify reasons accountable for geopolitical dispute over the water-deprived and politically unstable water resource. The focus in the literature, though, was mainly concerning with conflict resolution through improving water supply and increasing water resources as well as water share. The objective of this paper, instead, is to emphasize the importance of water demand management approach for conflict resolution. That is, demonstrate how strategies and actions that entail a proper utilization for the available water, hence; decrease conflict among countries and escalate peace and productive collaboration between various parties.

Notwithstanding the significance of identifying actual status of water conditions in the JRB with regards to water scarcity and increasing demand, and the importance of collaboration between the basin's riparian countries in light of the aforementioned challenges, there is still much work to be 
done. According to Allan (2002), water agreements and collaboration conventions have been lacking among riparian countries, throughout history. The JRB is not an exception. The sole agreement between Jordan and Israel regarding water is the one incorporated in the Peach Treaty signed between both countries in 1994. Albeit some of its clauses are debatable, the agreement provides a considerable example for potential cooperation among nations. The significance of studying the case of the JRB, as the main theme in this paper, is therefore two-dimensional. First, the study aspires identifying natural and induced key factors that affect water availability in the basin and understanding their impacts as catalysts for water conflict. Better understanding of these is expected to support and enhance collaboration efforts between Jordan and Israel, as stated in the agreement, to effectively manage the shared water resource. Moreover, propose modifications and improvements for some of the debatable clauses in the agreement, in correspondence to the changing environment and variable impacts. Second, Jordan, as a main water- beneficiary for the JRB, is a small economically disadvantaged country that endures severe climate, modest natural resources, and high influxes of refugees from troubled neighboring countries, mainly Syria and Iraq. The combination of those factors and others are deteriorating water security level in the country; thus, make it vulnerable to dispute over natural resources. Accordingly, discussing the potential for cooperation, information and knowledge sharing, and capacity building in water between countries are key factors to be considered in any water resolution plan. Furthermore, shedding the light on the success that has been achieved so far between Jordan and Israel in turning hydro-political conflict into an instrument for collaboration is anticipated to present the JRB as a model for countries of similar conditions and share the same challenge of water dispute both in the region and worldwide.

\section{Paper Outline}

This paper is divided into five sections. Section two reviews the prior literature about water as a scarce resource and the impact of water scarcity on generating tension towards geopolitical conflict among nations. Section three presents the proposed methodology used in exploring the inter-relationships between several factors such as water scarcity, economy and conflict. Section four discusses the model used and presents the assumptions and considerations for modeling the problem. It also introduces the scenarios examined and our simulation results. The paper finally concludes with a section discussing the main findings of the model and evaluates the relationship between various factors as it relates to water scarcity and conflict. Additionally, it proposes strategies to reduce the risk of conflict over water in Jordan and suggests prospects for proper water management policies and cooperation in the region.

\section{PRIOR WORK}

Water availability is significantly impacting humans, industrial activities, and environment. Fresh water accounts for only $2.5 \%$ of the available water on earth, of which merely $0.3 \%$ is left for extraction and human consumption (Rapacioli and Malone, 2012). In absolute term, water quantities are constant. Wolf et al. (2003a), Wolf (2007), and Ofori-Amoeh (2004), yet, argued that spatial distribution of water differs. Significant variations exist for water availability between states, countries, and regions. Water variability is attributed to, amongst other factors, natural cycles of physical weathering such as freezing and thawing, and variations in temperature. Other natural factors include rainfall variations, humidity, evapotranspiration, various runoff patterns, and climate change impacts. On the other hand, population boom combined with continuous and constant human activities besides rapid economic developments, all have exacerbated the pressure on sustainable resources, including water, particularly in arid and semi-arid regions (UNESCO, 2009; and FAO, 2012). In this context, water has increasingly becoming a 'unique' substance; and thus, water has been gaining an economic and political influence (Narasimhan, 2008).

Population growth adversely affects the availability of freshwater and its consumption. Hinrichsen et al. (1997) predicted an annual increase in the population by nearly 80 million people, which implied 
rising the demand on freshwater to around (64 billion cubic meters-bcm) annually (UNESCO, 2009). According to the estimates of the 2030 Water Resources Group, a research organization supported by the World Bank and private corporations, water demand would significantly outstrip the available water supply in 2030 by more than 40\%. According to Rapacioli and Malone (2012), this debate has been risen as water consumption patterns are growing among all sectors including domestic, industrial, and agriculture, where the latter has been already consuming a large share of water. This dilemma imposes challenges on governments and international organizations to achieve basic water needs aligned with increasing demand and attain sustainable water allocation to overcome water scarcity in the long term.

\section{Water as a Scarce Resource}

'Water scarcity' generally occurs when demand exceeds supply. Simply put; water resources such as rivers, lakes, or groundwater aquifers become no longer adequate to sustain the rising demand; thus, deficit occurs. Adversely, water deficit, in turn, would lead to rivalry between various parties expected to benefit from the water resource (UNESCO, 2009). Moreover, water scarcity is dynamic in nature. In this respect, water become scarce when demand increases and/or a decline in water quantity and/or quality exists. In contrast, scarcity might decrease considerably when proper water management approaches are considered (FAO, 2012). Examples on water management approaches include Integrated River Basin Management, Decision Support System analysis for water management, and other similar approaches, particularly in countries that are already facing water shortage.

In order to define water-scarce areas and assess water scarcity levels, hydrologists observe the per capita allocation of water. Areas with yearly per capita water allocation below $1,700 \mathrm{~m}^{3}$ are expected to face 'water stress' conditions, whereas areas or regions with annual per capita water supply below $1,000 \mathrm{~m}^{3}$ are likely to experience 'water scarcity'. If the annual per capita allocation drops significantly below $500 \mathrm{~m}^{3}$, then, 'absolute scarcity' conditions take place (UNESCO, 2012). Figure 1 shows freshwater availability and water scarcity levels worldwide. As the figure depicts, nearly more than half of the world's population approach water scarcity (Corcoran et al., 2010). This percentage is expected to increase by the year 2025. According to the United Nations estimates, 1,800 million inhabitants are expected to be living under 'absolute' water scarcity conditions, while nearly two-thirds will be experiencing 'water stress' conditions (Rapacioli and Malone, 2012; FAO, 2012; Uitto and Duda, 2002). Those figures tend to be higher in the Arab World countries, where most of the water bodies are shared.

Figure 1. Freshwater Availability Worldwide in 2011 (m3/person/year). Source: UNESCO.

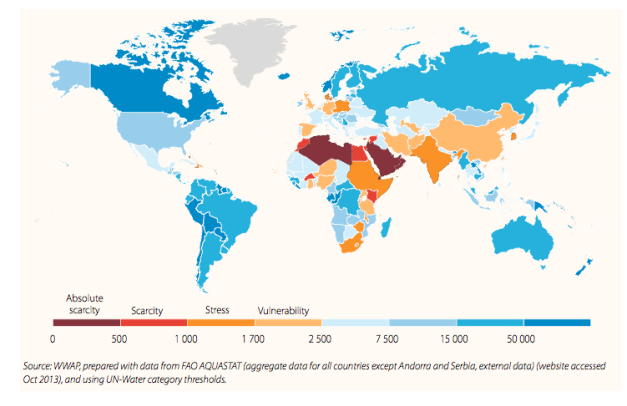

Smakhtin et al. (2004) debated that many river basin systems and aquifers are currently under water stress conditions. Smakhtin et al. debate further considered that the high rate of extraction from 
those water systems does not only impact water availability in countries that share the water body, but also severely impact ecosystems (Smakhtin et al., 2004). On the other side, the lack of water availability in those water-scarce basins boosts competition between users to satisfy the demand (UNESCO, 2009), a case to convert into a serious dispute or conflict over water resources.

Countries in the Middle East and North Africa Regions are classified as water-scarce areas (League of Arab States, 2009; Uitto and Duda, 2002). As Figure 1 indicates, most Middle Eastern countries such as Jordan suffer from 'physical water scarcity', a term reported by Rapacioli and Malone (2012) when more than $75 \%$ of water available from rivers is allocated to agriculture, industries, or domestic purposes. On the other hand, some countries in North Africa are endowed with water resources to accommodate their needs; yet, are suffering from 'economic scarcity', where less than $25 \%$ of water from rivers is withdrawn for human purposes (Rapacioli and Malone, 2012). To justify this paradox, it can be argued that a number of aquifers in the Arab World, for instance, are passing through sandstone rocks, namely Egypt, Libya, and Sudan. Some experts admit that although the volume capacity of such reservoirs is greater than the water replenished annually in the region by twenty times, water restoration rate does not surpass $2.5 \%$; therefore, water is insufficiently available (League of Arab States, 2009). Furthermore, some of the water resources in the Arab Region are shared by and regulated under Israeli occupation such as in the Syrian Golan and the Palestinian territories (League of Arab States, 2009); a situation that compounds the stress to managing those resources from a political viewpoint.

Water problem in the aforementioned regions is accredited to the lack of human and financial capacity, inefficient water institutional capacity, as well as unrest conditions and corruption in those regions. Accordingly, collaboration between highly and less developed countries, in terms of water resource management, would result in more effective water use; and thus, decrease water scarcity levels. Nevertheless, it can be claimed that generally when foreign countries engage in managing water resources in other countries, tension may exist, particularly if it is associated with political agendas. Consequently, increasing the level of dialogue between collaborative countries, again, would lead to less conflict between the various parties engaged in drawing the policies for sustainable development.

\section{Water-Related Conflict}

Throughout history, water has been symbolizing settlement, security, and stability both for countries and individuals. The current 276 watersheds that are shared by nearly $40 \%$ of the population, as reported by Furr et al. (2011), impose huge challenges on countries to manage water scarcity issues efficiently (Wolf et al., 2003a; Bach et al., 2012; and UNESCO, 2012). According to the Organization for Economic Co-Operation and Development (OECD), the increasing demand on water would intensify water rivalry among nations by 2030 , where around $47 \%$ of the population is expected to face water stress conditions (UNESCO, 2009). Furthermore, Davidson-Harden et al. (2007) proposed that the rise in population, particularly in areas that are already facing water stress conditions such as Asia and Africa, would further maximize tension between countries on water resources.

Nevertheless, Wolf et al. (2003b) argued that, historically, most of the water disputes have not turned into an actual 'water war' or formed a reason for militarized conflict. Instead, Wolf et al. (2003b) indicated that during the past five decades cases of collaboration exceeded water conflict, where only 37 cases of critical hydro-political dispute were recorded- mostly between Israel and its neighbors. Hensel et al. (2006), on the other side, claimed that water-deprived regions are more vulnerable to armed conflict, especially if water resources have a strategic or a political significance for the country (Voza et al., 2012). The main two examples that clarify this debate, according to Voza et al. (2012), are: "the conflict over Jordan River diversion projects" amongst Syria and Israel, as well as dispute between "Syria and Turkey over the Euphrates".

Nearly $90 \%$ of water-dispute cases between riparian countries discussed in the literature were over water quantity and water share (Wolf et al., 2005). Ohlsson (2000) identified two types of water-related conflict. The first type, according to Ohlsson (2000), is the conflict attributable to 
water scarcity, owing to the natural decrease in the quantities of water available for use. The other type of conflict is the one happens when inadequate strategies to manage and minimize the adverse impacts of water scarcity are followed, particularly in water-stressed countries. Examples on the latter type of conflict include constructing hydraulic storage structures as dams, which would result in negative social impacts such as displacement or resettlement of people (Van Der Molen and Hildering, 2005). This, in turn, would yield to major negative consequences on parties engaged in the planning process. This includes countries, on the international level, or internal stakeholders in charge of internal management policies within the state, on the state or country level. Wolf (1998), supported this debate and argued that the basis of dispute on transnational river basins mainly stems when one of the riparian countries initiate water-related developments within its jurisdictions. Such developments would affect other riparian countries during water scarcity periods, and ultimately initiate water disputes between neighbors. The main indicators for such dispute, according to Wolf, are linked to a number of factors such as water quantity and quality, management of multiple uses, and political agendas and partitions (Wolf et al., 2005). Other factors include geopolitical setting, level of national development, as well as undergoing hydro-political issues and institutional control of water resources (Nandalal and Simonovic, 2002).

\section{Relationship between Water Scarcity and Conflict}

It can be argued that water scarcity imposes macro impacts on the county's overall security and stability. In this respect, water deficiency forces governments to look for alternative resources for water, which increase tension with neighboring countries over resources (Fardous et al., 2004). Kirschbaum (1997) reviewed Gleick's framework about the interconnection between water scarcity and trans-boundary security. In that model, Gleick presented two arguments as drivers for transnational hydro-political conflict. The first argument considered the asset of water as a vital political and economic strength; and thus, securing its supply is a necessity to ensure security. In other words, securing water resources could motivate a militarized conflict in the case of water deficiency. This argument has been clarified by a number of factors to initiate or trigger armed dispute (Kirschbaum, 1997). According to Gleick, those factors include water scarcity level in the country, the amount of shared water supply among riparian states, political and economic influence of the neighbor countries, in addition to the ease of access to auxiliary sustainable water bodies (Kirschbaum, 1997).

The other argument discussed by Gleick identified water resource systems as a tool for dispute. Arguably, water resource systems such as water treatment plants, storage structures and facilities, as well as access to water resources like straits and rivers, can be used to enforce and support any political agenda or debate adopted by the strongest country (Kirschbaum, 1997). Recently, for instance, tension is rising on the boundary of the Strait of Hormuz between the Iranian side and the rest of the Arab State countries, namely in the Gulf area. The issue is escalating with the constant Iranian pressure to close or delay the access to the Strait of Hormuz, which represents the lively portal for most Gulf States' imports, including water. Given that most of the Gulf Cooperation Council (GCC) countries depend totally on this path for their water imports, such practices of controlling the access of a water resource from one side would cause water-related problems and intensify tension between countries; hence, produce undesirable consequences (Al Fathi, 2012).

\section{International Water Conventions on Conflict Management and its Effectiveness}

The rise of hydro-political tension amongst riparian countries on transnational water resource basins has trigged the formulation of various national and international water conventions, agreements, and collaborative institutions (Haftendorn, 2000; Raadgever and Mostert, 2005). Although approximately 450 agreements on international waters have been signed since the mid of the nineties of the past century, it has been claimed that around $60 \%$ of river basins and shared watercourses are still lacking to any effective and legal frameworks for collaboration (De Stefano et al., 2010; UNESCO, 2012). 
Two key conventions in this respect are the 'Helsinki Convention' (1992) on “The Protection and Use of Transboundary Water courses and International Lakes", and the "1997 United Nations Convention on the Law of the Non-Navigational Uses of International Watercourses" (Haftendorn, 2000, Chenoweth 2011). The general principle of the two conventions is to secure an equitable water allocation, for all neighboring countries, from the shared water resource. According to the UN Water Convention, the equitable water amount shall not negatively cause undesirable impacts to the other states on the border of the watercourse. The right of one country to use water in such a way, however, could be harmful to some of the riparian countries, since the impact or damage caused by using the obligated amount of water cannot be assessed. This issue could be resolved through collaboration and information sharing to ensure justifiable water share (Chenoweth 2011; Haftendorn, 2000; International Law Commission, 1997). A further principle that controls the relationships between riparian countries on transnational water bodies involves respecting the formally agreed rights of water share and utilization for other neighbor countries. Other principles include negotiating any water development initiatives, proposed by any of the riparian countries and aimed at increasing its share of water, besides increasing the collaboration between countries to protecting and conserving the quality of the water bodies (League of Arab States, 2009).

Arguably, water conventions have proven its effectiveness to manage water dispute over shared water resources. A number or international agreements, the Rhine River regime agreement for instance, have increased the collaboration and understanding between riparian countries in order to sustain the reliability of any developments on the shared watercourse between them. Moreover, many commissions have been established, and are actively involving, in resolving water related issues. This is being conducted by placing water challenges on top of their agendas to increase the institutional capacity and knowledge share, which in turn help to settle any dispute (Haftendorn, 2000). Nevertheless, Chenoweth (2011) critiqued many water international conventions, as they do not precisely identify how countries could define 'the justifiable water allocation' among parties. Instead, many of these conventions such as the UN Water Convention, stresses on the importance of considering all other issues and challenges related to water use and demand, socio-economic needs for instance, the degree of dependency on the water source, and the feasibility of other water resources (International Law Commission, 1997; Chenoweth, 2011).

\section{Cases of Water Conflict and Lessons on Cooperation and Conflict Prevention}

Wolf et al. (2005) and others claimed that conflict over water resources occurs on different geographical scales. Simply put; conflict could occur between two or more countries sharing the political borders (international dispute), or among intrastate parties (national dispute), in which tension could happen amongst various provinces and different groups inside the same country. Additionally, dispute could have a local indirect nature, where deviations in water allocation augment the instability inside cities; therefore, lead to a higher level of conflict. Water variability issue in Tajikistan represents an example on 'local dispute' over water. It can be argued that challenges of climate change and its consequences such as snow melting are likely to shift parts of the country toward water scarcity. Yet, parts of Tajikistan are already suffering from flash floods and landslides. Based on such geographical and water availability variations inside one country, potential for conflict between parties becomes higher.

As for international dispute that results when watercourses pass through various countries, additional pressure exists. Efforts, therefore, shall be concentrated on increasing the collaboration between all riparian countries. This has particular value in the case of most African and Asian countries. Among the noticeable examples of international hydro-political dispute in Africa is the SomaliEthiopian case. Studies have indicated that as a consequence of the frequent argues and conflicts between Somalia and Ethiopia, mainly with regards to the border issues, there has been a dearth in bilateral agreements that govern water exploitation and deployment of the Jubbah and Shebelle Rivers. Accordingly, increasing dialogue between the two parties with regard to the Somalia's most 
vital natural resources becomes a necessity, which would secure a sustainable life for the coming generations in that poor country (League of Arab States, 2009).

On the contrary, a good example of countries collaboration over water is between the Iraqi and the Iranian sides. In corresponding to the Iranian individual exploitation of the river-water resources shared with Iraq, and the latter disagreement, which presented before the international water law, an equitable share of the shared rivers was attained for the two countries. Specifically, the agreement admitted for both countries that are sharing the bank of the river to utilize a fair amount of water, without compromising the interests and rights of other riparian countries on the same river basin (League of Arab States, 2009). Further examples of successful cooperation over shared water are the Nile Basin Initiative, commenced in 1999, as well as the establishment of the Rhine Commission. Jaspers (2003) indicated that the Nile Initiative, adopted by the ten riparian countries along the Nile, has paved the road to formulate a joint base in order to implement a 'Shared Vision' approach aiming at managing water efficiently. That included the use of water, its resources, and the interaction between various parties for the benefit of the Nile (Jaspers, 2003). Other factors such as bridging the gap between neighboring countries, as well as supporting transnational investments with regards to shared water developments were considered (Nile Basin Initiative, 2010). On the other hand, the Rhine Commission, concerned mainly with the quality of water, was initiated to further controlling the dispute between upstream and downstream riparian countries (Jaspers, 2003; and Mostert, 1999). The commission has therefore been acting as catalyst for dispute resolution and has been resulting in better management of the shared water resources amongst countries.

\section{The Jordan River Basin Case}

Covering a total area of almost $18,300 \mathrm{~km}^{2}$ and passing through different riparian countries of Jordan, Israel, Palestine, Syria, and Lebanon, the JRB is one of the most critical international rivers to be managed. The basin system (the upper basin and the lower basin) has a total renewable volume of around 1,280 million cubic meters-mcm/year (Chenoweth, 2011). The basin consists of three major tributes: the Jordan, the Yarmouk, and the Zarqa Rivers (Courcier et al., 2005; Green Cross, 2006). The combination of the three river tributes makes the JRB the largest surface water resource in its region (Green Cross, 2006).

Currently, the total population served by the JRB on both the Jordanian and Israeli sides is approximately 13 million inhabitants. Of this total population, nearly 6.2 million are served in Jordan whereas around 7.1 million in Israel (Chenoweth, 2011). The three main rivers, the Dan, the Banias, and the Hasban Rivers, which are situated to the northern borders of Israel, formulate the beginning point of the Jordan River. The 'Upper River Basin', starting from Lebanon north of Lake Tiberias, is endowed with an average rainfall rate higher than $1,400 \mathrm{~mm}$ per year; thus, accounts for the lion's share of water in the river. The 'Lower Jordan River Basin' area covers around $83 \%$ of the total population in Jordan, besides $80 \%$ of agricultural activities including irrigation (Courcier et al., 2005; Stärk, 2007). Despite its significance in terms of securing water for most of the population in Jordan, the 'Lower Basin', particularly at the southern end, faces the challenge of low rainfall, with an annual average of less than $100 \mathrm{~mm}$ (Green Cross, 2006).

The Yarmouk River is the largest source of water in the basin (Green Cross, 2006; Fardous et al., 2004; Chenoweth, 2011). It formulates the hydro-political borders between Jordan and Israel from one side, as well as Jordan and Syria from the other (Courcier, 2005). With a total area of around 6,790 $\mathrm{km}^{2}$, mostly in Syria, around 1,160 $\mathrm{km}^{2}$ of the Yarmouk River lies in Jordan (Green Cross, 2006). According to Johnston plan (1955), the distribution of the river's total amount of (492 mcm/year) is divided between Jordan, Syria, and Palestine, with annual amounts of (337, 90, and $25 \mathrm{mcm} / \mathrm{year}$ ), respectively (Fardous et al., 2004).

The quality of water in the two river basins varies considerably. Despite the 'Upper Basin' has a relatively good water quality, the quality of the 'Lower Basin' water, which stretches from the Lake Tiberias until downstream, is considered poor (Chenoweth, 2011). Reasons for the low quality 
Figure 2. Jordan River Basin.

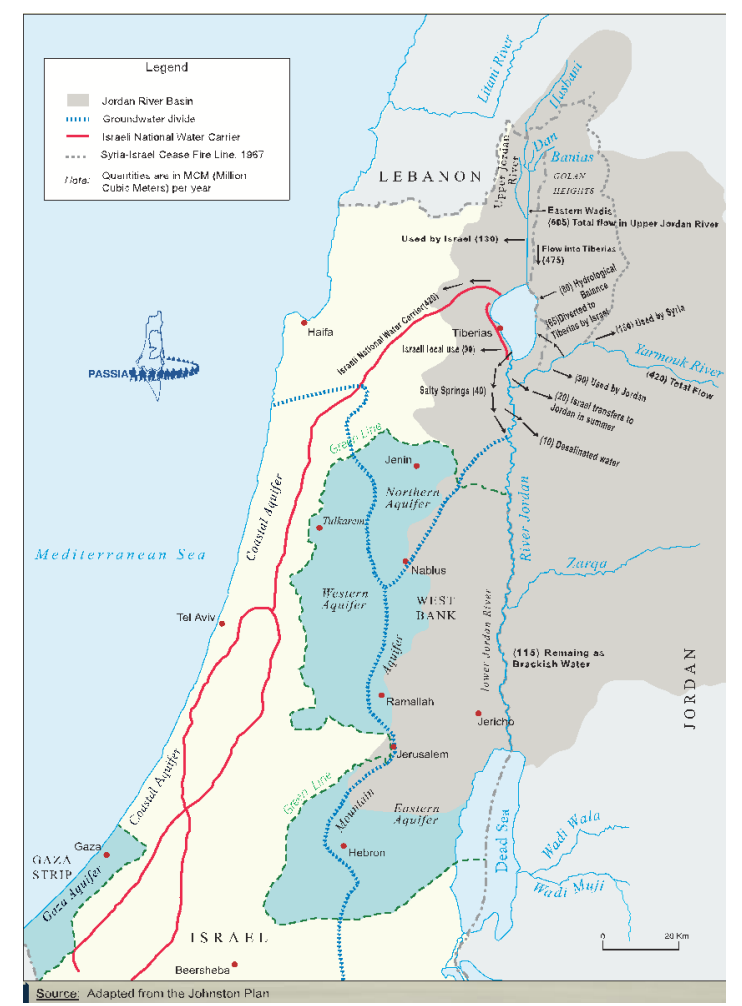

of water in the 'Low Basin' are attributed to natural as well as anthropogenic factors. Specifically, high salinity of water that results from the natural diversion of saline springs into the Lake Tiberias toward the downstream river affects the quality of water for consumption. On the other hand, $\mathrm{Al}$ Naem (2012) reported that wastewater effluent generated from the Israeli side to the southern part of the river impose drastic decline in the water quality. Chenoweth (2011) claimed that further induced factors such as irrigation discharge into the river deteriorate the quality of water in the 'Low Basin'.

Given the river's location in the middle of one of the most water-deprived regions, as well as highly politically unstable, in addition to many non-sustainable water practices involving water abuse and illegal groundwater abstraction, a dramatic decline in the available amount of water in the river system is recorded. Moreover, other factors including the increase in physical water scarcity besides climate change are all adversely impacting water resources in the countries bordering the river. According to Waslekar (2011), and based on recent findings on the impacts of climate change on water scarcity, Jordan River is expected to dry out to nearly $80 \%$ of its capacity in the coming few decades (Brown and Crawford, 2009). Continuous drought conditions that are happing all over Jordan are further exacerbating the problem (Tarawneh, 2011). Consequently, serious water challenges between the riparian countries on the basin are likely to occur; thus, countries' water share is likely to be contentious.

\section{PROPOSED METHODOLOGY AND THE SYSTEMS APPROACH}

System dynamics was applied to assess the vulnerability of the JRB and the impacts of water scarcity in Jordan on potential hydro-geopolitical dispute between Jordan and Israel. The assessment was 
conducted based on reviewing the number of water-beneficiaries in each country and projecting the total number of population to be served by the river basin in the coming 28 years (until 2042). In addition, the assessment considered evaluating the fresh water availability in Jordan and per capita water availability, as well as projecting the demand, deficit, and per capita water consumption for the horizon year. This aimed at finding the interrelationship between population growth, the increasing demand, and consumption of water, and the likelihood of potential conflict between the neighboring countries over the water resource.

In order to build the model, work entailed studying the causal relationship between numbers of factors that are believed to significantly affect water levels in the JRB, directly and indirectly. Relevant actions and alternatives were later proposed to achieve sustainable water resource management. Adopting those actions aims at avoiding dispute over the basin and ensuring continuous supply of water over time. To develop the model that represents the causal relationship between different variables and its impacts on water resources and conflict, Wilner model (2005) about the hydro-conflict and riparian politics was reviewed and modified for the case at hand. Wilner (2005) model essentially considers the following:

- Current and predicted scarcity levels within the region. This is based on finding the total amount of water available and the projected population, to assess the relationship between riparian counties,

The level of reliance on the shared water resource to sustains consumption needs, and

- The degree of collaboration between the riparian countries to finding new water resources, as well as adopting bilateral agreements and developing projects.

Correspondingly, VensimPLE ${ }^{\circledR}$ software was used to build the causal loop and stocks and flows models of the study. A positive sign between variables indicates that the change in one variable is directly proportional to the other, and leading to an even change, while the negative sign implies an adverse relationship. Both controllable and uncontrollable factors are included in the analysis.

It is worth mentioning that variables proposed in such predictive models are usually chosen subjectively by the model builder. This implies that chances of models to be missing significant variables become higher and cannot be eliminated afterword. In contrast, Biswas ed. (1976) believed that if the model constructed appropriately, it would present the future case in a way that can be evaluated extensively for various perspectives. Moreover, it can be utilized to analyze the sensitivity of response to any particular policy variable. Biswas ed. (1976) claimed that generally in water management analysis, environmental quality factors and economic efficiency criteria are determined or dealt with objectively as they are related to and deal with tangible and quantifiable factors.

In the light of this debate, to support our model, other variables were tested to reflect the actual status of the water problem in Jordan. This helped in studying in detail the relationship between the several factors identified in the model such as population, water availability, rainfall, and per capita freshwater availability, with water dispute. The following data and sources were consulted:

- The World Bank database for population census was consulted to find the total population figures in Jordan between 1992 and 2018. Population data for Jordan were verified by reviewing census data advertised on the official website of the Department of Statistics for the same period. Population growth rates for Jordan were also obtained from the aforementioned sources.

- Data on per capita renewable fresh water availability, demand, and total water availability in Jordan for 2010, 2030, and 2040 were acquired from Waslekar (2011) review about water in the Middle East, with specific focus on the JRB and its neighboring countries.

Linear regression was used to project total number of population, fresh water availability per person, and demand for the coming years up to 2042, to shed the light on factors believed to trigger 
conflict in the long-term. Deficit was further calculated by taking the difference between the total water availability in Jordan and demand projected for the study period (from 2018 to 2042). This factor alongside other factors such as climate change, drought, and increasing influx of refugees were discussed as they are considered to increase water scarcity levels in Jordan and in the JRB in particular; thus, trigger water dispute unless proper strategies are taken.

Additionally, rainfall data were analyzed to assess the long-term trend of rainfall in Jordan. Data were collected from the Jordan Metrological Department for the years 1976 to 2005, and for 2014. Linear regression was used to project rainfall for the coming years, until 2042; thus, measure rainfall and its variations in leading to scarcer water conditions.

Lastly, it is vital to mention that the model developed for the JRB is a general model that can be applied to any of the riparian countries on the basin. That is, any country could use this model to assess whether serious consequences for its water conditions exist or anticipated, in order to analyze and figure out best solutions to eliminate its water shortage problems and the potential for dispute, if expected. Nevertheless, the analysis in the coming section is mainly covering Jordan as one of the riparian countries of the JRB.

\section{System Model, Simulations and Results}

It can be argued that population growth and the high demand for water are the two utmost factors that lead to tension over water resources. Population growth is positively connected to demand and water consumption. That is, the higher the population, demand for water becomes higher to meet water consumption needs. Water consumption and demand are negatively connected to the water availability in the JRB. This explains that the higher the demand for water, the less is the water available in the basin, where the latter factor is negatively connected to the geopolitical conflict factor in the model. Simply put; the potential for conflict augments when less water is available in the basin, whereas the abundance of water in the basin eliminates hydro-conflict.

To assess the impact of population growth on the available water resources in Jordan, the number of indigenous population in the country was obtained for the base year (2018) and projected for the long-term period of 2042. According to research findings, the general population in Jordan is expected to overcome the 10 million inhabitants by 2042 . This implies that population plays a vital role in affecting water availability, knowing that an increase in population is associated with an increase in demand. Furthermore, given that the capacity of freshwater in Jordan is constant, around $(550 \mathrm{mcm})$ as reported by Waslekar (2011), demand is expected to reach up to $(1,887 \mathrm{mcm})$ in 2042 , while a considerable decline in the per capita water supply to around $(52 \mathrm{mcm})$ in the country is envisioned for the same period. As the demand continuous to outstrip the constant freshwater availability, water deficit is estimated to escalate and reach to $(1,337 \mathrm{mcm})$ in the horizon year. This suggests that the amount of water available will not sustain the growing demand of indigenous population. This case would trigger government to secure additional water quantities; consequently, tension might escalate over the already water-deprived basin- that is, the fist type of conflict that happens due to natural water scarcity as proposed by Ohlsson (2000).

Similarly, population is positively linked to many other factors that contribute to its growth and add challenges on the indigenous population such as urbanization and immigration influxes, to name a few. The highly unstable conditions and turmoil around the JRB geographical perimeter, and in some of its riparian countries, have been adversely influencing water problem in Jordan. Abnormal influxes of immigrants and refugees entering Jordan further compounded the issue. The cases of conflict in Palestine, Iraq, and more recently on the Syrian borders, for instance, have been increasing the pressure on the limited water resources in the country. This calls for increasing water allocation to meet growing demand and water consumption patterns; hence, declining the amount of water available in the JRB. Consequently, tension might initiate on the borders between Jordan and Israel owing to the fact that each country believes it has the right to use the shared water. 
Figure 3. Rainfall Pattern in Jordan from 1976-2042 (from Jordan Metrological Dept., 2012).

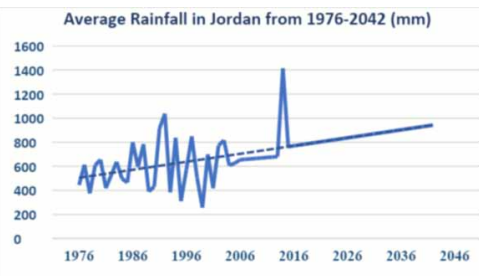

Another important factor that is significantly linked to water consumption, water availability, and geopolitical conflict is rainfall. Rainfall is positively related to water consumption, while the latter factor is negatively connected to the water available in the basin. The lower the rainfall amount, the scarcer the basin becomes; thus, less water is available for consumption. Figure 3 depicts the time series curve for rainfall in Jordan from 1976 to 2042. The figure indicates that rainfall pattern is highly changeable with time, as the relation is best fitted with an order six polynomial trendline. This uncertainty in rainfall pattern negatively impacts the availability of water in the basin, and boosts water scarcity levels in the long term. Drought, on the other hand, has been immensely impacting the rainfall pattern in Jordan, and has been causing more stressed water conditions (Tarawneh, 2011). Chenoweth (2011) argued that high temperatures and the effects of evaporation reduce runoff and infiltration; thus, decline the amount of water available in both ground and surface water resources. This would also trigger reasons for tension between countries, which could turn into conflict over water resources. In this regard, Chenoweth (2011) concluded that no long-term rainfall model perspective, water model, or water strategy is considered complete unless it involves climate change in its assessment. Although such models may not provide 'accurate' estimations; yet, they could be of considerable importance.

Implicit within the consumption exist factors such as meeting demands of e.g. farming, which play a crucial role in affecting water availability in Jordan and enhancing the potential of conflict. Fardous et al. (2004) reported that agriculture consumes the lion's share of water in Jordan, nearly $67 \%$ of the country water resources. Indeed, the rise in water allocated for supporting irrigation reduces water quantities and the share of water that are supposedly allocated for domestic use. This shortage in water supply coupled with an increasing demand will compound the burden of water availability in the JRB; therefore, increase hydro-political dispute between countries. Similarly, intrastate conflict could augment due to the shortage in domestic water allocation. Based on the model, water allocation is negatively related to customer satisfaction. Given that people believe that water is 'a right' that should be provided, balancing the domestic water allocation accordingly is a challenge that requires government to allocate a fair amount of supply to sustain the demand between several sectors.

Other factors such as deteriorated infrastructure are indirectly impacting the water availability in the JRB. Unaccounted for Water (UFW), that is water lost through leakage and poor distribution systems and /or illegal use of water, is also indirectly contributing to the problem. Nearly $35 \%$ of the water systems distributed in Jordan is lacking adequate infrastructure, and consequently resulting in a water shortage (Waslekar, 2011). According to the Ministry of Water and Irrigation estimates (2012) in Jordan, around $16 \%$ of the total water supplied is lost through unaccounted for water. Based on the model, the factor of inadequate infrastructure and leakage is negatively related to the water available in the JRB. This relation, however, is indirect. To illustrate, the increase in leakage and infrastructure deterioration decrease the amount of water supplied for customers; thus, decrease the satisfaction among them with regards to the service provided, in the model reflected as an implicit contributing factor to increasing regional tension, as this imposes pressure on water authorities to sustain expanding demand. 


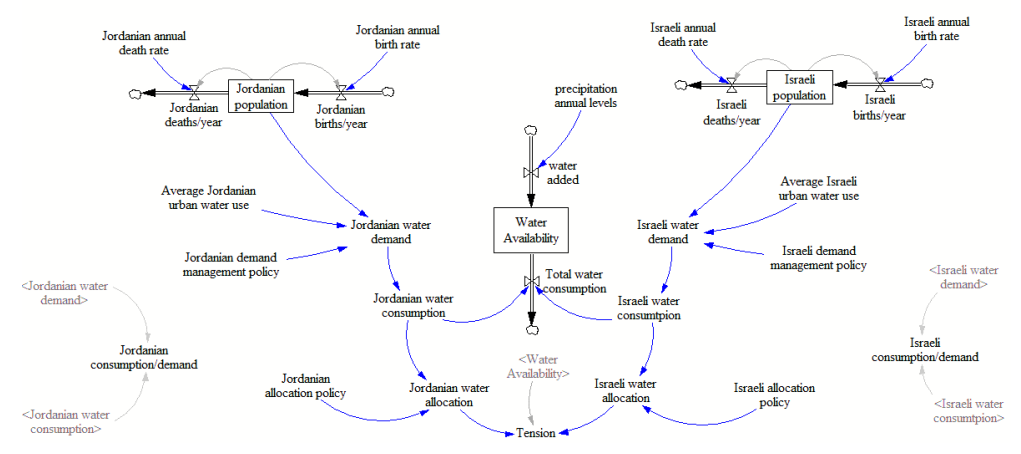

Therefore, increases the pressure on the JRB and drops water levels in the basin accordingly. Several reasons are responsible for the deteriorated infrastructure and inappropriate water distribution systems in Jordan. Institutional capacity, corruption, as well as poor management strategies trigger this situation, among other reasons. Consequently, building institutional capacity through continued training programs, and improving collaboration between national and international institutions for proper water system management promise to contribute to a solution. Furthermore, implementing monitoring systems to control illegal use of public water facilities, and enforcing laws govern this issue lead to better management strategies; and thus, decrease tension between regions, cities, and countries as well. This discussion is captured in Figure 4 as a stocks and flows System Dynamics model, derived from the earlier causal mapping exercise.

Based on this model we simulate 3 basic scenarios of duration from 2018-2028.

1) Without any demand management/institutional capacity building policy in place.

2) With a $200 \mathrm{MCM} /$ year water allocation policy for both; and

3) With a $200 \mathrm{MCM} /$ year water allocation policy for both and $25 \%$ reduced demand.

We see that tension decreases when we apply allocation policies, but as soon as the water is depleted, tension (and hence the potential for conflict) rises again. However, when we apply the demand management policy, people use less water preserving sustainability (there is still some available water in 2025).

We also ran 2 more simulations to see what happens beyond 2028 (period: 2018-2042), with policies of

1) $200 \mathrm{mcm} /$ year water allocation for both and $25 \%$ reduced demand; and

2) $200 \mathrm{mcm} /$ year water allocation for both and $35 \%$ reduced demand. In our experiments the policies are similar for both international parties for simplicity; we see that the more effective the demand management policies are, the better the impact on lowering the tension/potential for geopolitical conflict, as seen in the plots of Figure 5. Clearly, policy making on the understanding of water scarcity and thus giving emphasis on the demand management side of things (sustainability awareness, user behaviour, wastewater treatment and reuse etc.) has the potential for significant impact, whilst simple allocation policies without any further consideration produce worse results. Further analysis and interpretation of the results are then introduced in the following section. 

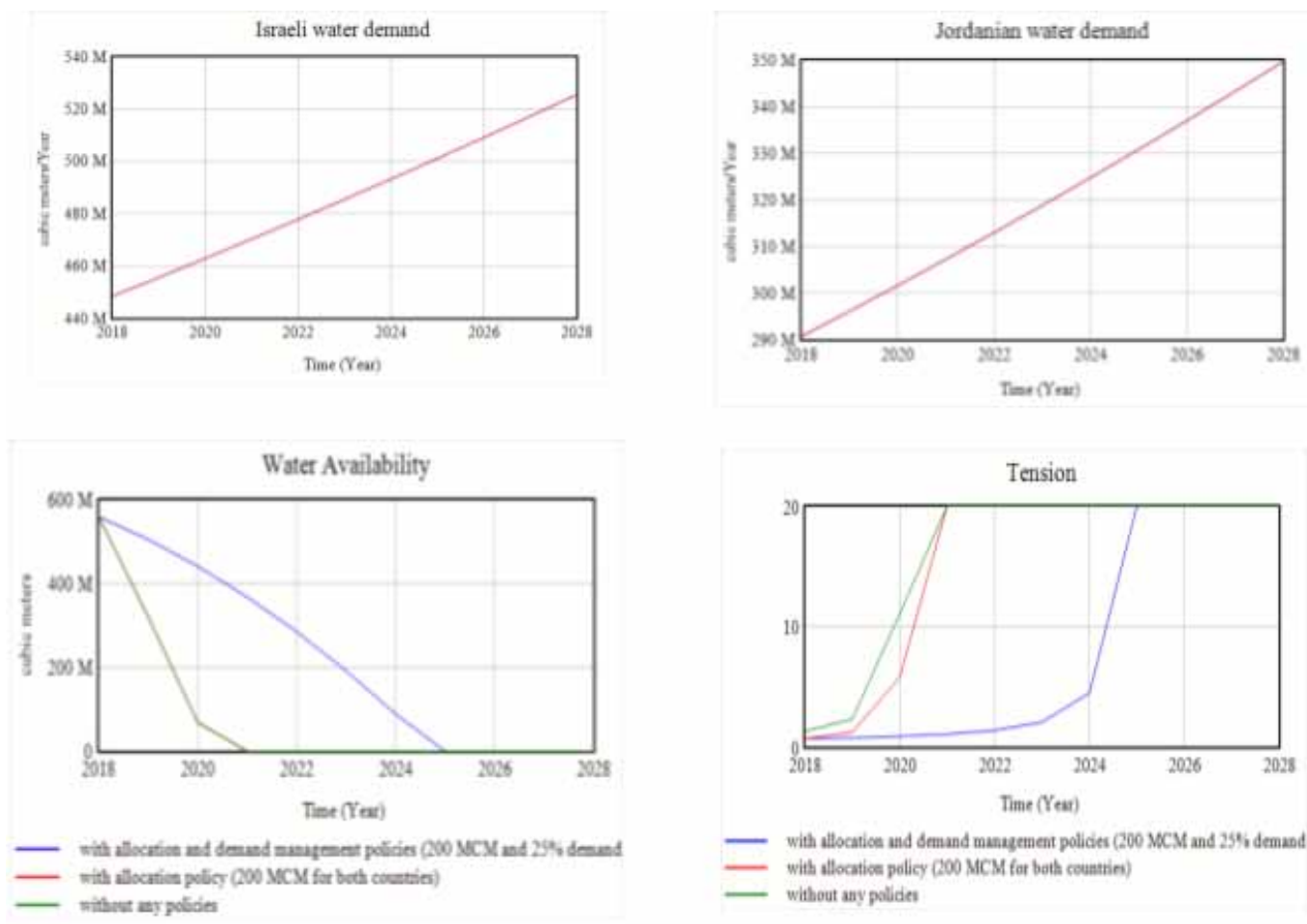

vith tllocatice und demand manazement polides (200 NCM and 25\% demand with illocatice policy 200 MCM far both counties: without ayy polides
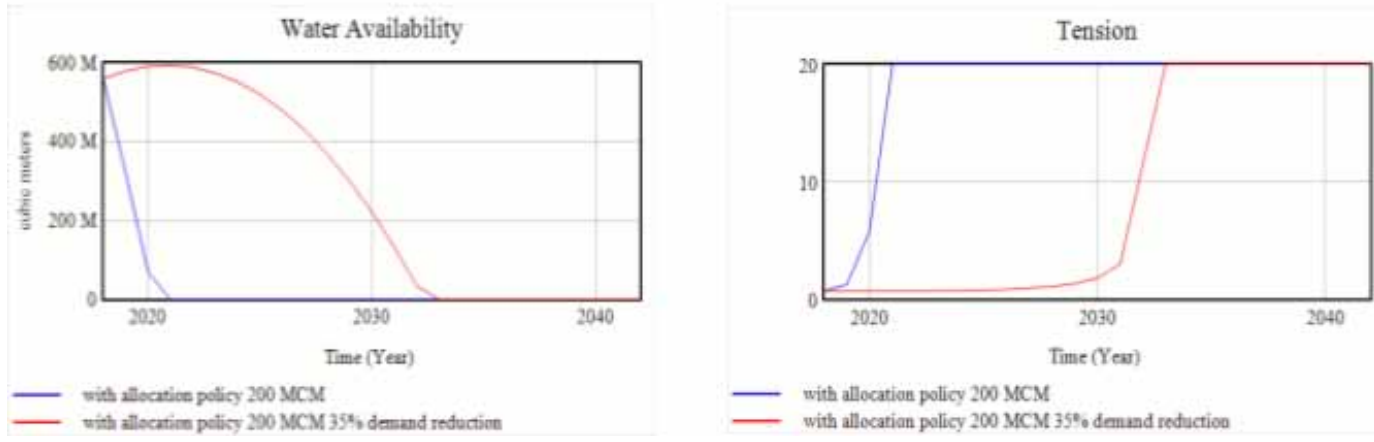

\section{CONCLUSION}

Jordan is undergoing water stress conditions. The decline in water status in Jordan and in the JRB in particular is owed to several reasons prominently, rainfall variations, population growth, and rising demand. Population and demand projections for the long-term period indicated a rise in population and demand up to year 2042. Turmoil and political unstable conditions around the JRB are indirectly linked to the water burden in Jordan. The increase in indigenous population associated with immigration influxes are further expected to raise the total number of inhabitants to be served by the JRB; hence, raise water supply and allocation needs. Demand for water in the country is further expected to exceed the available water supply; thus, water deficit is estimated to escalate in the horizon year. This suggests that the amount of water available will not sustain the bourgeoning demand of indigenous population. To accommodate water population needs in this respect, government needs to guarantee 
additional water quantities from the already water-stressed basin and propose alternative resources; consequently, tension might escalate over time.

In this paper, system dynamics modelling was used to investigate the relationship between water vulnerability in the JRB and the potential for geopolitical conflict between two riparian countries, Jordan and Israel. The causal relationships between several factors that are believed to augment water scarcity in the JRB were firstly identified in a causal loop diagram and later turned to a dynamics model. The model provides illustrations on how water quantities in the basin, and thus potential related conflict, are influenced by those factors. Each factor presented in the model can be turned into a tool to apply productive water management approaches and effective collaboration strategies that will ultimately attain sustainable water allocation.

Rainfall variability is expected to compound the problem. Scarce water conditions, which are augmenting by low rainfall amounts, decrease water quantities available for abstraction. The analysis suggested that rainfall variations are further worsening due to climate change, temperature variations, and drought. This implies that tension between countries could turn into conflict over water resources. In the case of the JRB, considerations of abnormal risks such as climate change and drought were not incorporated in the Pease Treaty signed by Jordan and Israel in 1994. The treaty, which devoted a specific section related to water issues and management between the two countries, did define a set amount of water to be allocated for both countries instead of determine percentages for water allocation from the available amount of water.

According to Article Six of the Peace Treaty, Israel is to provide Jordan with $(20 \mathrm{mcm})$ in summer from the Jordan River, while Jordan have to provide $(20 \mathrm{mcm})$ from the Yarmouk River in winter in return (Israel-Jordan Peace Treaty, 1994). In other words, the treaty did ignore the consequences of any adverse future conditions like climate change, drought, and unexpected population; thus, it did not attain securing a justifiable amount of water for the two riparian countries to sustainably meet future demand. It can be argued that leaving those factors undefined in any water agreement escalate hydro-political conflict if one of the parties could not provide the agreed amount of water due to uncontrollable conditions. A perfect example is the case of severe drought recorded in the region in the late nineties of the past century that restrained Israel from providing Jordan with the agreed amount of water; claiming that rainfall was not adequately enough at that time (Brown and Crawford, 2009; Wolf et al., 2009). In this respect, reviewing the articles addressing water in the Peace Treaty is one of the viable options to decrease water deficit in the country and to eliminate potential clashes in the future. This entails studying the possibility of redistributing the share of water based on the percentage of total population to be served by the basin on each side, and expected demand.

According to the results, excessive water consumption of agricultural activities decreases the amount of water available in the JRB. This results in two-dimensional impacts as it triggers intrastate as well as interstate tension over water resources. Specifically, the use of outdated methods in agriculture and irrigation increases agricultural water consumption and reduces the water available for domestic use. This indirectly impacts customer satisfaction, and leaves government with two options. The first option is re-distributing available water quantities among several sectors such as domestic and agriculture; thus, not sustain the needs for either sector. This would enhance intrastate tension between parties. The second option is increasing water abstraction from the basin to meet the growing demand, a practice that results in exceeding the agreed limits between the riparian countries; therefore, major interstate conflict could take place.

To resolve water challenges within this context, applying the 'Shared Vision Approach' in water resource management is encouraged. This entails consulting water-beneficiary parties and local organizations at different levels including several water-demand sectors; government representatives; agricultural parties; local people; and NGOs, to arrive at a mutual agreement for best practices to be followed in water and river basin management. Examples in this light include encouraging the reuse of reclaimed wastewater for irrigation purposes and practicing high-tech irrigation methods. Government, on the other side, is sought to propose policies to control water consumption in agriculture. In this 
respect, government is required to effectively implement and enforce the legislations governing water abstraction and exploitation for agricultural use.

Furthermore, government may impose an incremental tax system for water prices for agriculture; based on the amount of water used and the total irrigated area. The higher the agricultural area and the amount of water used, for example, the higher the price of water collected. Benefits of adopting this approach are two-fold. First, water will be preserved from being wasted. Second, agricultural sector will be improved by eliminating obsolete irrigation and agricultural methods that are consuming water intensively. Notwithstanding those benefits, this approach may gain public opposition, particularly within poor to middle income classes. Proper implementation is therefore needed to eliminate intrastate conflict that could further develop to an interstate dispute.

Pollution of water resources further escalates tension among riparian countries. According to $\mathrm{Al}$ Naem (2012), continues wastewater effluent from Israel to the southern part of the Jordan River have been declining the quality of water in the river. This, in turn, increases pollution level in the basin. The decline in the quality of water, accordingly, decreases the amount of water in the river that is safely available for abstraction for consumption, and drives conflict to arise regarding the distribution of water. Therefore, collaboration between the riparian countries on reducing pollution level in the basin is a necessity, in order to secure an amount of water with acceptable quality for sustainable use. This collaboration can be achieved through knowledge sharing as well reviewing best practices concerned with attaining high water standards to meet future demand.

\section{Proposed Strategies to Reduce the Potential of Hydro-political Conflict in Jordan}

Based on the aforementioned analysis, it can be argued that hydro-political conflict between Jordan and Israel is envisioned unless the two countries follow appropriate actions to meet the bourgeoning demand. Generally, most of the management strategies for water-shared resources are designed based on qualitative integration between various sectors to achieve mutual objectives. Biswas ed. (976) argued that some of the objectives are complementary, while others are conflicting, leading to a failure in meeting the objectives that are originally envisioned. In this regard, water policy planners shall focus on developing a holistic framework of strategies and alternatives in order to meet, to the extent possible, the desired outcomes of water collaboration.

It is believed that cooperation between riparian countries on shared water resources is a fundamental strategy that countries constantly work on to improve. Nevertheless, collaboration itself would not alleviate water shortage problems, mainly in countries with deteriorated water situation such as Jordan. Accordingly, water policies and management strategies shall focus on complementary aspects to tackle water shortage. Those include, among other aspects, the supply solutions and demand management, which can be applied on a unilateral basis. While most of the literature focuses on increasing the supply and looking for new water resources, Kirschbaum (1997) claimed that demand management strategies would indeed result in promising outcomes to minimize the impacts of water shortage on transboundary disputes.

The case of the JRB and Jordan in particular is unique in terms of its location, water scarcity level, and constant instability and clashes between countries bordering the Jordan River. The following strategies are therefore aiming at helping Jordan to effectively manage its water resources, so, reduce or eliminate potential geopolitical impacts over transboundary resources. Within this context, government needs to formulate a comprehensive strategy encompasses several parties that govern water situation in Jordan. This entails working with several parties at the political, social, and financial levels to ensure positive progress of the policy implementation. Moreover, this requires involving all individuals, stakeholders, politicians, economists, investors, and large industrial installations and community to achieve an integrated demand resource management policy. One of the viable strategies to eliminate conflict and increase the availability of water in the country is to apply 'demand management' strategies that result in better conflict resolution as well as decrease pressure on the limited water 
resources. This could be implemented on the community level and national level including industrial and agricultural sectors, as well as the international level between neighboring countries.

In terms of reducing water consumption, government required to consider individuals-domestic sector as well as industrial sectors. For individuals, government may adopt an accelerated incentive regime for water consumption, which allows individuals to obtain different types of incentives as they achieve reductions in water consumption. If water consumption reduces by a certain percentage, for instance, a reduction in water bill by the same percentage is granted. The higher the reduction in water is therefore reflected on the water bill. This would encourage individuals to reduce their consumption in order to receive higher reductions on their water bills, which would ultimately save water resources and reduce water scarcity. Similarly, government may develop incentive regime for industrial activities and factories with different rates and incentives. In this regard, government may connect the reduction achieved in water consumption with the taxes acquired from industrial sector. If an industry achieves a reduction in water consumption, taxes therefore reduce by the same percentage of the reduction achieved in water use. This approach would further encourage factories and industries to adopt water-efficient practices and eventually preserve water in the county.

One form of collaboration over the JRB is that riparian countries need to collect and monitor data and samples from the Jordan River on a regular basis, and update data periodically to be constantly informed with any variations in the quality and quantity of the water river. In order to actively achieve this strategy, it is suggested that both countries collaborate in building a 'database center' that contains all relevant data and information, all in one place, to share knowledge among various parties and discuss any potential initiatives that aim at maximizing the benefits gained from using the River. Although large investments are required to build and manage such an informative center, the center would work as an information hub for all riparian countries and considerably benefit all parties concerned with the case of the Jordan River management. Benefits include sharing institutional and capacity building experiences, educational and scientific improvements, as well water management approaches proposed for the benefit of water utilization.

On the supply side, the option of desalination holds promising prospects for water in the MENA. Kirschbaum (1997) pointed out that desalination represents a vital water conversion example that aims at providing additional sources of water to sustain increasing demand. Given the fact that desalination in Jordan is yet amateur, collaboration between Israel, as one of the leading countries in desalination in the world, would yield significant benefits. This collaboration could be conducted under the aforesaid proposed 'database center', which could further enhance the outcomes of the collaboration. Notwithstanding the large befits of desalination as a water conversion resource, it can be argued that desalination is not feasible from an economic as well as an energy consumption basis. Accordingly, proper planning for desalination projects is required, particularly in resources-deprived and economically disadvantaged countries such as Jordan, to effectively accomplish sustainable, achievable, and relevant alternatives to meet future demand, while reducing rivalry over transboundary water resources.

\section{Further Work}

Based on the above discussion, it becomes crucial for policy consultations on water and conflict resolution to engage community members and parties in order to achieve desired outcomes. Policy consultations and the government need to focus on two levels during policy formulation: community level and international level. Methodologically, this work could inform either levels if placed for example in the context of SD-facilitated public policy frameworks, such as the one described by Nasution et al. (2018).

On a community level, there is a need to promote awareness related to water scarcity, water management, climate change, and the use of common applications such as water saving devices to improve the efficiency of water use. Alongside promoting aspects of conservation and efficiency, efforts need to highlight the importance of periodic water audits and the importance of conducting 
them. It is believed that increasing the level of awareness about the problem would trigger creative and innovative solutions to optimize consumption. Moreover, government needs to focus on preparing comprehensive plans to enforce water harvesting in the country, mainly in domestic sector. This would prevent wasting rainfall water and help individuals to utilize rainfall from households' roofs.

Aside from that, there is a need to increase the level of awareness about water scarcity situation in Jordan and about where Jordan is ranked among countries in terms of available water resources. More importantly, identify the impacts of geopolitical and economic burdens of the lack of water resources on the national security and stability.

On the international level, riparian countries need to foster a culture of conversation, collaboration, and knowledge and resource sharing in order to effectively tackle shared water problems. In this respect, it is recommended that Jordan and Israel move forward in the construction of the 'Dead-RedSea Water Conveyance Canal Project'. The project is funded by the World Bank and holds promising prospects for supplying the riparian countries with additional water quantities and decreeing deficit, as well as preserving the level of the Dead Sea, that has been declining continuously since the past few year (Quba' a et al. 2017). Although the project was termed and agreed on in the late 2005; yet, it has been delaying from a political, economic, and environmental perspectives. Therefore, resuming the dialogue between countries concerning with the project implementation, namely Jordan, Israel, and Palestine, and adopting the project will decrease the pressure on the shared water resource, increase collaboration between countries, and improve water supply and allocation for inhabitants served by the JRB. The project is also envisioned to save the environment and ecosystem of the Dead Sea basin as well ${ }^{1}$. 


\section{REFERENCES}

Abdulla, F., van Veen, W., Abu Qdais, H., van Wesenbeeck, L., \& Sonneveld, B. (2018). The Impact of Climate Change on Water Availability and Recharge of Aquifers in the Jordan River Basin. Climate Change and Global Warming. doi:10.5772/intechopen.80321

Al Fathi, S. (2012). The Strait of Hormuz - again. Gulf News. https://gulfnews.com/business/opinion/the-straitof-hormuz-again-1.1046050

Al Naem, M. (2012). Israel is Withdrawing the Rest of Jordan River Water. AlArab AlYawm. http://alarabalyawm. net

Allan, A. J. (2002). Hydro-Peace in the Middle East: Why no Water Wars? A Case Study of the Jordan River Basin. SAIS Review (Paul H. Nitze School of Advanced International Studies), 22(2), 255-272. doi:10.1353/ sais.2002.0027

Bach, H., Bird, J., Clausen, T. J., Jensen, K. M., Lange, R. B., Taylor, R., Viriyasakultorn, V., \& Wolf, A. (2012). Transboundary River Basin Management: Addressing Water, Energy, and Food Security. Mekong River Commission.

Biswas, A. (Ed.). (1976). Systems Approach to Water Management. McGraw-Hill, Inc..

Brown, O., \& Crawford, A. (2009). Rising Temperatures, Rising Tensions Climate change, and the risk of violent conflict in the Middle East. International Institution for Sustainable Development.

Carius, A., Dabelko, G., \& Wolf, A. (2004). Water, Conflict, and Cooperation. Policy Brief -The United Nations and Environmental Security.

Chenoweth, J. (2011). Will the water resources of Israel, Palestine, and Jordan remain sufficient to permit economic and social development for the foreseeable future? Water Policy, 13(3), 397-410. doi:10.2166/ wp.2010.131

Corcoran, E., Nellemann, C., Baker, E., Bos, R., Osborn, D., \& Savelli, H. (Eds.). (2010). Sick Water? In The central role of waste- water management in sustainable development. A Rapid Response Assessment. United Nations Environment Program, UN-HABITAT, GRID-Arendal.

Courcier, R., Venot, J. P., \& Molle, F. (2005). Historical transformations of the lower Jordan river basin (in Jordan): Changes in water use and projections (1950-2025). Comprehensive Assessment Research Report 9. Colombo, Sri Lanka: Comprehensive Assessment Secretariat.

Davidson-Harden, A., Naidoo, A., \& Harden, A. (2007). The geopolitics of the water justice movement. The Geopolitics of the Water Justice Movement Peace Conflict \& Development, 11.

De Stefano, L., Duncan, J., Dinar, S., Stahl, K., \& Wolf, A. (2010). Mapping the Resilience of International River Basins to Future Climate Change-induced Water Variability. World Bank Water Sector Board Discussion Paper Series 15. The World Bank.

Fardous, A., Mudabber, M., Jitan, M., \& Badwan, R. (2004). Harnessing Salty Water to Enhance Sustainable Livelihoods of The Rural Poor In Four Countries in West Asia and North Africa: Egypt, Jordan, Syria And Tunisia. Report, Ministry of Agriculture, Hashemite Kingdom of Jordan.

Furr, K., Null, S., \& Parker, M. (2011). International River Basins: Mapping Institutional Resilience to Climate Change. Wilson Center. https://www.wilsoncenter.org/event/international-river-basins-mapping-institutionalresilience-to-climate-change

Gholizad, A., Ahmadi, L., Hassannayebi, E., Memarpour, M., \& Shakibayifar, M. (2017, April-June). A System Dynamics Model for the Analysis of the Deregulation in Electricity Market. International Journal of System Dynamics Applications, 6(2), 1-30. doi:10.4018/IJSDA.2017040101

Givatia, A., Thirelb, G., Rosenfeldc, D., \& Pazd, D. (2019). Climate change impacts on streamflow at the upper Jordan River based on an ensemble of regional climate models. Journal of Hydrology. Regional Studies, 21, 92-109. doi:10.1016/j.ejrh.2018.12.004 
Green Cross. (2006). Water for Peace, The Jordan River Basin. http://www.greencrossitalia.it/ita/acqua/wfp/ jordan_wfp_001.htm

Guma, I. P., Rwashana, A. S., \& Oyo, B. (2018, January-March). Food Security Indicators for Subsistence Farmers Sustainability: A System Dynamics Approach. International Journal of System Dynamics Applications, 7(1), 45-64. doi:10.4018/IJSDA.2018010103

Haftendorn, H. (2000). Water and international conflict. Third World Quarterly, 21(1), 51-68. doi:10.1080/01436590013224

Hensel, P. R., Laughlin Mitchell, S. M. C., \& Sowers, T. E. II. (2006). Conflict management of riparian disputes. Political Geography, 25(4), 381-411. doi:10.1016/j.polgeo.2005.11.001

Hinrichsen, D., Robey, B., \& Upad-Hyay, U. D. (1997). Solutions for a Water-Short World. Population Reports Series M, No. 14. Baltimore, MD: Population Information Program, Johns Hopkins School of Public Health.

Hussein, H., Natta, A., Al Kareem Yehya, A., \& Hamadna, B. (2020). Syrian Refugees, Water Scarcity, and Dynamic Policies: How Do the New Refugee Discourses Impact Water Governance Debates in Lebanon and Jordan? Water (Basel), 12(2), 325. doi:10.3390/w12020325

International Law Commission. (1997). Convention on the Law of the Non-navigational Uses of International Watercourses, 1997. United Nations Webserver.

Jaspers, F. (2003). Institutional arrangements for integrated river basin management. Water Policy, 5(1), 77-90. doi:10.2166/wp.2003.0004

Kershner, I. (2013). A Rare Middle East Agreement, on Water. The New York Times. https://www.nytimes. com/2013/12/10/world/middleeast/israel-jordan-and-palestinians-sign-water-project-deal.html

Kirschbaum, M. (1997). Water Resources: Security Impacts in the Jordan River Basin. A Research Paper, the Research Department Air Command, and Staff College.

League Of Arab States. (2009). Managing shared Water Resources: The Arab Region's Experience. Author.

Mostert, E. (1999). River Basin Management and Planning; Institutional Approaches and Results in five European Countries and six International Basins. BRA Series on River Basin Administration, Research Report No 10, BRA Centre.

Nandala, K., \& Simonov, S. (2002). State-of-the-Art Report on Systems Analysis Methods for Resolution of Conflicts in Water Resources Management. A Report Prepared for Division of Water Sciences UNESCO.

Nandala, K., \& Simonov, S. (2003). Resolving conflicts in water sharing: A systemic approach. Water Resources Research, 39(12), 1362.

Narasimhan, T. N. (2008). Water, law, science. Journal of Hydrology (Amsterdam), 349(1-2), 125-138. doi:10.1016/j.jhydrol.2007.10.030

Nasution, F. B., Bazin, N. E., Rosalyn, R., \& Hasanuddin, H. (2018, October-December). Public Policymaking Framework Based on System Dynamics and Big Data. International Journal of System Dynamics Applications, 7(4), 38-53. doi:10.4018/IJSDA.2018100103

Naugle, A. B., Backus, G. A., Tidwell, V. C., Kristin-Keller, E., \& Villa, D. L. (2019, January-March). A Regional Model of Climate Change and Human Migration. International Journal of System Dynamics Applications, 8(1), 1-22. doi:10.4018/IJSDA.2019010101

Nikabadi, M. S., \& Hajihoseinali, A. (2018, April-June). E-Waste Recycling System in Closed Loop Supply Chain. International Journal of System Dynamics Applications, 7(2), 55-80. doi:10.4018/IJSDA.2018040104

Nile Basin Initiative. (2010). About the NBI. https://www.nilebasin.org/newsite/index.php?option=com_conten $\mathrm{t} \&$ view $=$ article \&id=139\%3Aabout-the-nbi\&catid=34\%3Anbi-background-facts \&Itemid=74\&lang=en

Ofori-Amoah, A. (2004). Water Wars and International Conflict. University of Wisconsin-Eau Claire. http:// academic.evergreen.edu/g/grossmaz/oforiaa/

Ohlsson, L. (2000). Water conflicts and social resource scarcity. Physics and Chemistry of the Earth. Part B: Hydrology, Oceans and Atmosphere, 25(3), 213-220. doi:10.1016/S1464-1909(00)00006-X 
Quba'a, R., El-Fadel, M., Najm, M., \& Alameddine, I. (2017). Comparative assessment of joint water development initiatives in the Jordan River Basin. Intl. J. River Basin Management, 15(1), 115-131. doi:10.1080/1571512 4.2016.1213272

Raadgever, G.T., \& Mostert, E. (2005). Transboundary River Basin Management-State-of-the-art review on transboundary regimes and information management in the context of adaptive management. Deliverable 1.3.1 of the NeWater project, RBA Centre, TU Delft.

Ragab, R., \& Prudhomme, C. (2002). Climate change and water resources management in arid and semi-arid regions: Prospective and challenges for the 21st century. Biosystems Engineering, 81(1), 3-34. doi:10.1006/ bioe. 2001.0013

Rapacioli, S., \& Malone, R. (2012). Thirsty Planet. Chartered Institute of Management Accountants.

Sherwood, H. (2013). Dead Sea neighbors agree to pipeline to pump water from Red Sea. The Guardian. https:// www.theguardian.com/world/2013/dec/09/dead-sea-pipeline-water-red-sea

Simonovic, S. P. (2009). New thinking, Water Resources Management: A Systems View. Stockholm International Water Institute. https://www.siwi.org/documents/Resources/Water_Front_Articles/2009/WRMASystemsView. pdf

Smakhtin, V., Revenga, C., \& Döll, P. (2004). Taking into account environmental water requirements in globalscale water resources assessments. Comprehensive Assessment Research Report 2. Colombo, Sri Lanka: Comprehensive Assessment Secretariat.

Stärk, K. (2007). Water using conflicts in in the lower Jordan River basin, optimal water allocation with a special reference to the agricultural sector (Diploma thesis). Universität Passau lehrstuhl für physische geographie.

Tarawneh, Z. (2011). Water Supply in Jordan under Drought Conditions. Water Policy, 13(6), 863-876. doi:10.2166/wp.2011.094

Treaty Of Peace Between The State Of Israel and The Hashemite Kingdom Of Jordan. Article (6), signed October 26, 1994 (Referred to in the text as the Israel-Jordan Peace Treaty, 1994).

Uitto, J., \& Duda, A. (2002). Management of transboundary water resources: Lessons from international cooperation for conflict prevention. The Geographical Journal, 168(4), 365-378. doi:10.1111/j.00167398.2002.00062.x

UNESCO -World Water Assessment Program. (2009). The United Nations World Water Development Report 3: Water in a Changing World. Author.

UNESCO -World Water Assessment Program. (2012). The United Nations World Water Development. Report 4: Managing Water under Uncertainty and Risk. Author.

UNESCO- World Water Assessment Program. (2014). The United Nations World Water Development Report 2014: Water and Energy. Author.

Van Der Molen, I., \& Hildering, A. (2005). Water: Cause for conflict or co-operation? Journal on Science and World Affairs, 1(2), 133-143.

Voza, D., Vuković, M., Carlson, L., \& Djordjević, D. (2012). International Water Conflict and Cooperation: The Role of Power Relations among Riparian's. International Journal of Humanities and Social Science, 2(11), 56-66.

Waslekar, S. (2011). The blue peace, rethinking middle east water. Swedish International Development Corporation Agency.

Water Scarcity. (2012). Food and Agriculture Organization Of The United Nations (FAO). http://www.fao.org/ $\mathrm{nr} /$ water/topics_scarcity.html

Wilner, A. (2005). Freshwater Scarcity and Hydro-political Conflict: Between the Science of Freshwater and the Politics of Conflict. Journal of Military and Strategic Studies, 8(1).

Wolf, A., Kramer, A., Carius, A., \& Dabelko, G. D. (2009). Peace in the pipeline. BBC News. http://news.bbc. co.uk/1/hi/sci/tech/7886646.stm 
Wolf, A., Yoffe, S., \& Giordano, M. (2003b). International Waters: Identifying Basins at Risk. Water Policy, 5(1), 29-60. doi:10.2166/wp.2003.0002

Wolf, A. T. (1998). Conflict and corporation along international waterways. Water Policy, 1(2), 251-265. doi:10.1016/S1366-7017(98)00019-1

Wolf, A. T. (2007). Shared Waters: Conflict and Cooperation. Annual Review of Environment and Resources, 32(1), 241-269. doi:10.1146/annurev.energy.32.041006.101434

Wolf, A. T., Kramer, A., Carius, A., \& Dabelko, G. D. (2005). Managing Water Conflict and Cooperation. In State of the World 2005: Redefining Global Security. W.W. Norton.

Wolf, A. T., Stahl, K., \& Macomber, M. F. (2003a). Conflict and cooperation within international river basins: The importance of institutional capacity. Water Resources, 125, 31-40.

\section{ENDNOTES}

1 On December 9, 2013, the ministers of water and irrigation of Jordan; energy and infrastructure of Israel; and minister of water of the Palestinian Authority signed the agreement and official papers to construct the Dead-Red-Sea Water Conveyance Canal Project, at the Washington headquarters of the World Bank. According to the minister of water and irrigation of Jordan, effective implementation of the project would start in the third quarter of 2015 while tenders for the first phase would be solicited for local and international firms in November of the same year. The first phase entails building and operating desalination plant in Aqaba to provide around $1,000(\mathrm{mcm})$ a year for use in southern Israel and southern Jordan through diverting brine water from the Red Sea into fresh water (Sherwood, 2013; Kershner, 2013). Authors Note: This agreement represents a prefect example for collaboration among riparian countries, and supports the arguments that conversation and knowledge sharing between countries are key factors for water conflict resolution, and that dispute over water resources could be eliminated; and instead, used as an instrument for collaboration and development to improve water conditions in all riparian countries.

Raya A. Al-Masri is a researcher in the Centre for Environment and Sustainability (CES) at the University of Surrey. Her research focuses on the governance and management aspects of the Water-Energy Nexus (WEN), with particular interest in the case of Jordan. She is developing an integrated governance framework for better WEN management in the country via exploring policymaker's perspectives on the WEN, their understanding of it in terms of institutional collaboration, governance, and planning, and by this exploring possible schemes for nexus governance and collaboration. Prior to joining the CES, Ms. Al-Masri worked as a consultant in the development sector, where she worked on projects related to integrated resource management and sustainability and community based environmental solutions. She holds an MSc. in Water and Environmental Management from the University of Bristol, and a BSc. in Civil Engineering from the University of Jordan. Ms. Al-Masri is also a member in the Charted Institute of Water and Environmental Management (CIWEM).

Theodoros Spyridopoulos is a Senior Research Engineer at Bristol Research and Innovation Laboratory, Toshiba Europe Limited in Bristol. He was awarded his PhD from the University of Bristol (UoB) in 2016. He has been doing research on modelling and simulations of cyber capabilities using Game Theory, System Dynamics and the Viable System Model to develop holistic cyber-security methods for the protection of complex critical cyberphysical systems. His current research lies in the field of Cyber Security for Industrial loT, with particular focus on end-to-end security, security modelling and Al for security and security for Al.

Stylianos Karantzas is Research Project Manager with the Department of Civil Engineering, University of Patras. He holds the degrees of PhD in Civil Engineering from the University of Patras and MBA from the University of Bath.

Vasiliki Lazari holds diploma in Civil Engineering and MS in "Intelligent Transportation Systems and Project Management" from University of Patras. The MS thesis topic is "Resource allocation optimization in large construction projects using evolutionary algorithms". She is a PhD candidate in Department of Civil Engineering, University of Patras, in "Smart Infrastructure Management" and her research interests are in optimization techniques and artificial intelligence (linear programming, genetic algorithms, heuristic and meta-heuristic techniques) in several domains such as transportation and workforce planning solutions.

Theo Tryfonas holds a Chair of Infrastructure Systems and Urban Innovation at the Department of Civil Engineering, University of Bristol, UK. He is a computer scientist with expertise in urban data, the loT and Smart Cities. He is a Chartered Fellow of the BCS, The Chartered Institue for IT, and a Fellow of the Royal Society for Arts, Manufactures and Commerce (RSA). 